\title{
IAMJ
}

INTERNATIONAL

AYURVEDIC

MEDICAL JOURNAL

Review Article

ISSN: 2320-5091

Impact Factor: 6.719

\section{A CONCEPTUAL STUDY ON ETIOLOGY AND AYURVEDIC MANAGEMENT OF MUKHADUSHIKA W.S. R TO ACNE VULGARIS: A REVIEW}

\author{
Gupta Deepak ${ }^{1}$, Asthana Alok ${ }^{2}$ \\ ${ }^{1}$ PG Scholar, PG Department of Kriya Sharir, Ch, Brahm Prakash Ayurved Charak Sansthan, Khera, \\ Dabar, Najafgarh, New Delhi, India \\ ${ }^{2}$ Associate Professor, PG Department of Kriya Sharir, Ch, Brahm Prakash Ayurved Charak Sansthan, Khera, \\ Dabar, Najafgarh, New Delhi, India
}

Corresponding Author: Dk23gupta@gmail.com

https://doi.org/10.46607/iamj3509072021

(Published Online: July 2021)

Open Access

(C) International Ayurvedic Medical Journal, India 2021

Article Received: 30/06//2021 - Peer Reviewed: 09/07/2021 - Accepted for Publication: 10/07/2021

Check for updates

\begin{abstract}
Ayurveda is considered an ancient healthcare system of India which is based on the eternal principle of healthy life. The whole clinical approach of Ayurveda is based on the preventive, promotive \& curative aspects that aim of Ayurveda. Now a days, the whole world is gradually turning towards Ayurveda for a safe and complete cure of diseases, especially in the field of skin problems, Ayurveda can contribute remarkably. Skin is known as the largest organ of the human body, which performs many functions like thermoregulation, vitamin D synthesis, sensory perception, immunological function etc. But besides this, it also seems an important symbol of beauty. Acne vulgaris is the most common problem affecting the normal texture of skin bothering teenagers today. This skin condition lights the mankind and caricature of youth. Acne vulgaris is known as a disease of the pilosebaceous follicle characterized by non-inflammatory (open and closed comedones) and inflammatory lesions (papules, pustules, and nodules). Four major factors involved in the disease production are inflammation, rise in sebum production, cornification of pilosebaceous ducts and microbial involvement. In Ayurveda, Shalmali thorn-like eruptions on the face of a youth caused by Kapha, Vata and Rakta are known as Yuvanpidika. They are also known as Mukhadushika. ${ }^{1}$ The painful eruptions packed with Meda, similar to the thorns of Shalmali having their site on the face of adults are known as Yuvanpidika ${ }^{2}$. This article describes the Ayurvedic review of Mukhadushika with Nidan, Pur-
\end{abstract}


varoop, Roop, Samprapti and Chikitsa along with its modern counterpart of Acne with its definition, causative factors, and types of acne, complications and treatment modalities.

Keywords: Mukhadushika, Ksudrarogas, Yuvanpidika, Acne vulgaris, Shalmali

\section{INTRODUCTION}

Acne vulgaris is a chronic inflammation of the pilosebaceous gland. It is characterized by the formation of comedones, erythematous papules and pustules, less frequently nodules or cysts and in some cases scars. It is a condition of skin with a significant cutaneous and psychological diseased burden. It affects both males and females in almost equal frequency. Acne occurs most commonly during adolescence and often continues into adulthood. Across the globe, it affects $80 \%$ of individuals between puberty to thirty years of age. There are many factors responsible for acne-like, constipation, mental stress, hormonal imbalance, climatic conditions, cosmetics etc. Although the exact pathogenesis of acne is not known, several interrelated pathogenic mechanisms are available for its actual cause like increased sebum production, follicular epidermal hyperproliferation, microbial colonization (especially propionibacterium) and release of inflammatory cell mediators (mainly cytokines). Acne vulgaris mostly affects the areas of skin with the densest population of sebaceous follicles these areas include the face, the upper trunk, and the deltoid region. ${ }^{3}$ According to Ayurveda aggravation of Kapha, vata and sonata (rakta) lead to the formation of Shalmalikantaka (thorn) like eruptions on the face. These pidika mainly affects the youth population thus known as Yuvanpidika or Mukhadushika. In Ayurveda Samhita, Shamana and ShodhanaChikitsa are two basic types of treatment mentioned for any kind of roga. Shamana Chikitsa followed by Shodhana Chikitsa is the most effective treatment for Yuvanpidika or Mukhdushika.

A. AIM AND OBJECTIVES: To elaborate and discuss the aetiology and Ayurvedic management of Mukhadushika (Acne Vulgaris)

B. MATERIAL AND METHOD: Literary material is collected from the textbook of modern medicine and Ayurvedic Samhitas. Medical research
Journals and available commentaries of Ayurvedic Samhitas have also referred to collect relevant matters.

\section{PREDISPOSING FACTORS ${ }^{4,5}$}

Oils, Facials, Cosmetics, Friction on the face, Pregnancy, Stress, Sunlight, etc. are some predisposing factors. These factors create some conditions in the body, favouring the occurrence of Acne. These factors can be enlisted as:

1) Diet-Diet is not likely to affect acne vulgaris appreciably but most of the dermatologist has mentioned certain components of diet which may play an aggravation or production of acne. Butter, cream, chocolates, ice cream, fats, excess starches, fried foods, sweets, greasy dishes, overeating, alcohol etc.

2) Climate - A hot and humid climate aggravates acne, due to increased sweating causing ductal hydration. Many occupations (soldiers wearing a uniform for long, cooks; people working with oils and chemicals like halogenated hydrocarbons) provide a conducive atmosphere for the development or aggravation of Acne.

3) Use of Cosmetics- Acne is frequently seen in women who use oil-based cosmetics for long periods, also acne often follows facial massage.

4) Occupation- Occupation related stress, hot and oily environments in industrial areas can also aggravate acne.

5) Constipation- A common predisposing cause to produce acne is intestinal stasis, especially constipation. Regular bowel movement is an essential part to eliminates toxins through the stool from the body. Without this regulatory movement, the detoxification system is suboptimal which may indirectly lead to symptoms like acne vulgaris. 
6) Mental Stress - There is no evidence that sebaceous glands are under nervous control but there is no doubt that mental stress can aggravate acne. Severe acne may also be related to increased anxiety and anger. The stress causes excessive secretion of androgens and subsequently leads to acne vulgaris.

7) Menstrual Cycle- About $70 \%$ of female complains of aggravation of acne as a premenstrual symptom, probably it may relate to premenstrual oedema of the pilosebaceous duct.

8) Psychological Factors -Severe acne is related to increased anxiety, depression, poor self-image, and poor self-esteem.

\section{CLINICAL TYPES OF ACNE ${ }^{6,7}$}

There are several types of acne found commonly.

1. Acne punctata

2. Acne papulosa

3. Acne pustulosa

4. Acne indurata

5. Acne cystic

6. Acne keloida

\section{SYMPTOMS}

- Skin rash or lesion on the face, upper trunk, and deltoid region.

- Comedones (whiteheads or blackheads)

- Pustules

- Cysts

- Papules

- Nodules
- Redness (erythema) in the skin or skin around the lesion

- Inflammation around the skin eruptions, crusting of skin eruptions and scarring of the skin.

\section{CLINICAL FEATURES/MORPHOLOGY}

- Most of the patients with severe acne have greasy skin with patulous follicular openings.

- Eruptions are polymorphic, characterized by the presence of comedones, inflammatory lesions and scars at the same time.

- Comedones: Two main types of comedones are recognized that is open comedones and closed comedones.

- Inflammatory lesions vary from small papules with an erythematous also too superficial deep pustules with tenderness and fluctuant nodules.

- Scarring can occur as a result of injury to the skin during the healing process of active acne. There are two types of scars atrophic and hypertrophic depending on whether there is a loss or gain of collagen fibres. Atrophic type is more common than hypertrophic type. The atrophic scar is again subdivided into three types based on shapes that are ice-pick, rolling and boxcar. Hypertrophic scars also called keloidal scars which are associated with excess deposition of collagen fibres due to decreased collagenase activity.

\section{- GLOBAL ACNE GRADING SYSTEM ${ }^{8}$}

The local score for each area is calculated by following.

Table 1: Grading for Acne vulgaris

\begin{tabular}{|l|l|l|l|}
\hline Location factor & Score & Types of Lesions & Score \\
\hline Forehead & 2 & No lesion & 0 \\
\hline Right cheek & 2 & Comedone & 1 \\
\hline Left cheek & 2 & Papules & 2 \\
\hline Nose & 1 & Pustules & 3 \\
\hline Chin & 1 & Nodules & 4 \\
\hline Chest \& upper back & 3 & & \\
\hline
\end{tabular}

LOCAL SCORE $=$ Factor multiply by Grade $(0-4)$

C. The severity of the acne can be graded on clinical grounds as under: ${ }^{9}$
- Grade I: Comedones, occasional papules (Mild)

- Grade II: Papules, comedones, few pustules (Moderate) 
- Grade III: Predominant pustules, nodules, abscesses (Severe)

- Grade IV: Mainly cysts, abscess, widespread scarring (Cystic)

Treatment: The treatment of acne can be divided into:

(1) Topical therapies

(2) Internal therapies

1. Topical therapies:

* Topical retinoids These are comedolytics. Retinoic acid, adapalene, Benzoyl peroxide are used.

* Topical antibiotics Clindamysin (1-2.5\%), Erythromycin (2-4\%) Other- Sulphur, $\alpha$ Hydroxy acid, Azelaic acid etc.

\section{Internal therapies}

* Antibiotics Tetracyclines, Doxycycline, Minocycline is more used. Less frequently erythromycin and azithromycin are used.

\section{* Hormonal therapy}

- Anti-androgens Cyproterone acetate: $2 \mathrm{mg}$ c.a. and $35 \mu \mathrm{g}$ ethinylestradiol Spironolactone: 50$100 \mathrm{mg}$ Isotretinoin: $0.5-1 \mathrm{mg} / \mathrm{kg}$ body weight for 12-16 days

- Oestrogens- In severe acne and premenstrual flare of acne.

MUKHADUSHIKA: Shalmali thorn-like eruptions on the face of a youth caused by Kapha, Vata and Rakta are known as Yuvanpidika. They are also known as Mukhadushika. ${ }^{4,5}$ The painful eruptions packed with Meda, like the thorns of Shalmali having their site on the face of adults are known as Yuvanpidika.

\section{H. NIDANA PANCHAKA}

Any disease is studied under following five factors in Ayurveda:

1. NIDANA ${ }^{10}$

- Aharaja Nidana-Katu, Guru, Madhura, Atisnigdha, Dadhi, Amla, Usna, Vidahi, Tikshna, Lavana, Madha, Masa, Ajirnebhojanam, Adhyasana

- Viharaj Nidana- Vegavidharana, Jagarana, Nidra Viparyaya, Upavasa, Atapasevana

- Manasika Nidana-Atishoka, Ksobha, Krodha, Santapa
- Kalaja Nidana-Sharadkal Svabhava (Avasthikkal), Yuvaavastha

- Antahstravi Granthis- Endocrinal factor like increase in progesterone and androgen activity thus sebaceous gland becomes hyperactive which is responsible for hyperplasia of oil glands.

\section{Purvarupa}

The Purvarupa originates before the onset of a proper disease but purvarupa of Mukhadushika are not specifically mentioned by any Granthakara.

3. Rupa $^{11}$

- Shalmali Kantakakara- The eruptions that are conical in shape, found on the face, resembling the Kantaka (thorn) of the Shalmali tree and having it's based on the face is called Yuvanpidika.

- Pidika- The lesion which appears in the form of eruption is known as Pidika.

- Saruja- The painful eruptions. Pain may be severe or mild.

- Ghana- The word Ghana is derived from thick, solid, hard or indurated. The Pidika which is Ghana on touch is due to vitiated Kapha.

- Yuna Mukhe- This disease affects usually an adult face. This word shows the site of origin of acne and the time of occurrence of the disease. Mukha is the outer part of the face which includes cheeks, forehead, nose, chin etc.

- Medogarbha - The eruption is impregnated with Meda dhatu. This Meda Dhatu is collected and packed in the eruption as sebum is collected in the sebaceous gland ${ }^{12}$.

4.Upshay-Anupshaya- When the drugs, diet, or daily lifestyle results in beneficial effects directly or indirectly in a disease process is known as Upshaya and when it results in a negative effect, then it is called Anupshaya.

Upshaya- Local hygiene and diet which will not aggravate Kapha, Vata and Rakta dosha

Anupshaya- All Aharaja and Viharaja, which are described under Nidana of the disease includes under Anupshaya. 


\section{Samprapti-13}

Table 2: Samprapti Ghatak

\begin{tabular}{|l|l|}
\hline Dosha & Kapha, Vata \\
\hline Dushya & Dhatu -Rakta, Meda, Rasa \\
\hline Upadhatu & Twaka \\
\hline Mala & Sweda, Twakagatasneha \\
\hline Srotasa & Rasavaha, Raktavaha, Swedavaha \\
\hline DushtiPrakara & Sanga \\
\hline Sthana & Twaka \\
\hline RogaMarga & BahyaMarga \\
\hline
\end{tabular}

Putting under the heading of Kshudraroga, the pathogenesis of Mukhadushika is not given in Ayurvedic texts. But as no disease can occur without Samprapti. The knowledge of pathogenesis is helpful in the treatment of the disease. There is not any single disease that can occur without vitiation of Doshas. According to Acharya Sushruta Yuvanapidaka or Mukhadushika is caused by the vitiation of Vata, Kapha and Raktadosha. He does not include Pitta as a causative factor but in the practice, one can see such patients of Yuvanapidika who having the symptoms of swelling, redness, and burning sensation which confirms the involvement of Pitta in the pathogenesis. The reasons for neglecting Pitta may be due to its similarity with Rakta in the character. If Rakta is involved, then Pitta will always be associated with it. Moreover, the site of Pitta is said in Sweda and Rakta. If Rakta and Sweda are vitiated Pitta will be vitiated jointly with them. According to Acharya Charaka if aggravated Pitta is located in the skin and Rakta dhatu then it causes redness and swelling which can be called Pidaka. Thus, it is concluded that the Pitta is also involved in the production of Yunanapidika. The disease Yuvanapidika is said to be produced by the waste product of Sukra, the seventh dhatu of the body, but some Acharyas said that the Sneha of the face is the waste product of the Majja dhatu.

MANAGEMENT ${ }^{14,15}$ In Ayurvedic text mainly two types of Chikitsa are described that are Shamana (internal medicine and external applications of drugs) and Shodhana Chikitsa. Following some therapies are to be advised for the disease Mukhadushika.

\section{Shodhana Chikitsa}

a. Vaman Karma

b. Virechana Karma

c. Nasya Karma

d. Shiravedhana

2. Shamana Chikitsa- For Shamana therapy many herbs-mineral compounds are being advocated either for internal or external medication.

Single Drugs (EkalaYoga)- Lodhra, Manjistha, Usheera, Padmakha, Haridra,

Formulations (AushadhaYoga)-

a. Vati- Arogyavardhinivati, Keshoraguggulu, Panchatiktahaghritaguggulu,

b. Kwath- Maha Manjisthadi Kwatha, Khadirashtak Kashaya, Patoladi Kwath, Sarivadhyasava,

c. Churna- Manjisthachurna, Panchnimbadichurna, Triphlachurna, Giloya churna

d. Lapa- Lodhradhilepa, leshalmali-kalkadi-lepa, jatiphaldilepa

e. Ghrita (medicated ghee)- Mahatikktaghrita, Panchatiktakaghrita, Tiktashatpalaghrita,

- Apathya- Avoid hot, spicy, oily, fried, pungent food, junk food, fast food and Virudha Ahara, food that is incompatible with each other such as milk with fish, etc.

- Pathya-Food items with Tiktarasa like Patola, Giloya, Methika, etc., fresh green and leafy vegetables and enough water intake (especially lukewarm water)

- Yoga and Meditation-Yoga Therapy suggest Pranayama, Asana, Shatkarma, and meditation are useful to combat the mansika nidana of Mukhadushika. 


\section{CONCLUSION}

Mukhadushika is a common skin disease that affects the beauty of the face, especially in adolescence age. It can be cured by using Shamana and Shodhana therapy with the use of different herbs-mineral drugs mentioned in Ayurveda.

\section{REFERENCES}

1. Illustrated susruta Samhita Text by prof K. R. Srikantha Murthy, English translation vol 1, sharirsthan chapter 4verse 13, Chaukhambha Orientalia reprint year 2017, vanarasi

2. Asthanghrdayam text, prof K.R.Srikantha Murthy, English translation, uttarsathan chapter 31 verse 5, Chaukhambha Krishnadas Academy edition 2013, Varanasi.

3. www.wikipedia free encyclopedia.com/acne Vulgaris article by Julie $\mathrm{C}$ harper, from Acne vulgaris

4. The study of the life of KumkumadiGhrita prepared by Kumkum and Nagakeshar and its effect on Mukhadushika, 2009 by Amrita Anee

5. Acne dermatology, a symposium at the world congress of dermatology Paris, 2002, 206/1/103

6. Harrison's Principles of Internal medicine, vol. 1, edited by Kasper, Braunwald, Fauci, Hauser, Longo, Jameson, edition $16^{\text {th }}$, p.n. 295

7. www.aad.org/media/background/news/releases/millio ns of women facing adult acne.

8. Doshi A, Zaheer A, Stiller MJ. A comparison of current acne grading systems and a proposal of a novel system. Int J Dermatol 1997:36:416-8.

9. Tulakne M A, Chari K V R 'Acne rosacea and perioral dermatitis.' Book and Atlas of Dermatology, $2^{\text {nd }}$ edition, Mumbai, Bhalani publishing house; 2001,

10. Agnivesha, Charak Samhita with Vidyotini english Commentary vol;2 by R. K. Sharma and Vaidya Bhagwan Das, sutrasthan, chapter 8verse 24:

Chowkhanbha Sanskrit Series office vanarasi. Reprint, 2011.

11. Kalyanakaraka, Ugraditacharya, Seth Govindaji Raoji, Joshi, Sakharam, Nemchandra Grantha mala, 1940, Kshudrarogadhikara, 57 shlokas, p.n. 302

12. The study of shelf life of Kumkumadi Ghrita prepared by Kumkum and Nagakeshar and its effect on Mukhsdushika, 2009 by Amrita Anee

13. English Translation Vagbhata Astangahrdaya, Dr. K. N. Udupa, vol - 3, uttarashan chapter 31 verse 5, pub- lisher chowkhambhakrishnadas Academy, edition, 2012 varansi.

14. Illustrated susruta Samhita Text by prof K. R. Srikantha Murthy, English translation vol 1, chitshasthan chapter 20verse 37, Chaukhambha Orientalia reprint year 2017, vanarsi.

15. English Translation Vagbhata Astangahrdaya, Dr. K.N. Udupa, uttarashan chapter 17 verse 4, publisher chowkhambha krishnadas Academy, edition, 2012 varansi.

\section{Source of Support: Nil \\ Conflict of Interest: None Declared}

How to cite this URL: Gupta Deepak \& Asthana Alok: A Conceptual Study On Etiology And ayurvedic Management Of Mukhadushika W.S. R To Acne Vulgaris: A Review. International Ayurvedic Medical Journal \{online\} 2021 \{cited July 2021\} Available from: http://www.iamj.in/posts/images/upload/1538_1543.pdf 